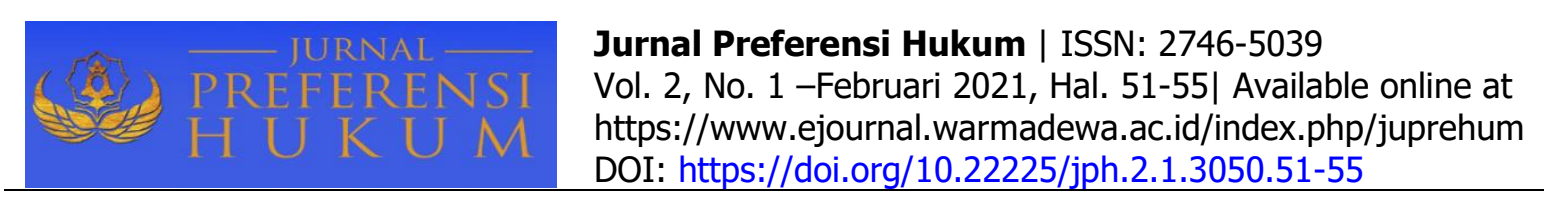

\title{
PERLINDUNGAN HUKUM TERHADAP HAK WARIS ANAK YANG LAHIR DARI PERKAWINAN TIDAK DICATATKAN
}

\author{
Ni Luh Putu Ayu Lestari, Ni Luh Made Mahendrawati, I Ketut Sukadana \\ Fakultas Hukum Universitas Warmadewa Denpasar, Bali, Indonesia
}

\begin{abstract}
Abstrak
Sahnya perkawinan apabila dilaksanakan sesuai ketentuan adat dan agama serta dicatat sesuai aturan UndangUndang yang berlaku, sehingga memperoleh akta sebagai bukti adanya perkawinan. Akan tetapi dalam masyarakat banyak yang melakukan pernikahan tanpa mengurus akta nikah dan mencatatkan perkawinannya dicatatan sipil, akibatnya akan berdampak pada anak yang dilahirkan, oleh karena itu perlu adanya perlindungan hukum terhadap mereka. Penelitian ini bertujuan untuk mendeskripsikan kedudukan anak yang dilahirkan dari perkawinan tidak dicatatkan sebagaimana ketentuan UUP dan menjelaskan perlindungan hukum bagi hak waris anak yang lahir dari perkawinan tidak tercatat. Penelitian ini menggunakan tipe hukum normatif dengan pendekatan Undang-Undang dan pendekatan konseptual. Sumber bahan hukum yang digunakan adalah sumber bahan hukum primer yang terdiri dari UUD 1945, KUHPerdata, Undang-Undang Perkawinan, dan Undangundang tentang Perlindungan Anak, dan sumber bahan hukum sekunder terdiri dari makalah-makalah dan jurnal yang relevan dengan penelitian ini. Hasil penelitian menunjukkan bahwa kedudukan anak yang lahir dari perkawinan tidak dicatatkan adalah sah jika sudah memenuhi ketentuan masing-masing agama dan kepercayaan, namun perkawinan tersebut tidak memiliki kekuatan hukum dan anak yang dilahirkan tidak mendapat perlindungan hukum yang menyangkut hak warisnya kelak. Anak luar kawin tersebut akan mendapat warisan apabila ada bukti otentik berupa akta kelahiran sebagai alat bukti tertulis yang sah.
\end{abstract}

Kata Kunci: Perlindungan Hukum, Perkawinan Tidak Dicatatkan, Hak Waris Anak

\begin{abstract}
The validity of a marriage if it is carried out in accordance with the provisions of custom and religion and is recorded in accordance with the applicable laws, so that a deed is obtained as evidence of marriage. However, in many societies who carry out marriages without taking care of a marriage certificate and registering their marriages as civil records, the result will have an impact on the children born, therefore there is a need for legal protection for them. This study aims to describe the position of children born from unregistered marriages as stipulated in the UUP and to explain the legal protection for the inheritance rights of children born from unregistered marriages. This study uses a normative law type with a constitutional approach and a conceptual approach. The source of legal material used is the source of primary legal material consisting of the 1945 Constitution, the Civil Code, the Marriage Law, and the Law on Child Protection, and the secondary legal material sources consist of papers and journals relevant to this research. The results showed that the position of children born from unregistered marriages was legal if they had fulfilled the requirements of each religion and belief, but the marriage did not have legal force and the child who was born did not receive legal protection regarding his / her future inheritance rights. The out-of-wedlock child will inherit if there is authentic evidence in the form of a birth certificate as a valid written evidence.
\end{abstract}

Keywords: Legal Protection, Undocumented Marriage, Inheritance Rights of Children

\section{PENDAHULUAN}

Perkawinan adalah suatu perbuatan suci yang sangat mulia sebagai bentuk peresmian hubungan antara pria dan wanita yang bertujuan membentuk keluarga atau rumah tangga yang bahagia demi meneruskan garis keturunan, maka UU No. 1 Tahun 1974 tentang Perkawinan (UUP) harus dilaksanakan oleh semua masyarakat Indonesia. Di Indonesia pencatatan perkawinan sangat penting hal ini ditandai dengan adanya pengaturan mekanisme yang jelas tentang proses pencatatan perkawinan (Usman, 2017). Sebuah perkawinan harus dibuktikan dengan adanya bukti tertulis yang sah yang dikeluarkan oleh lembaga Negara yang berwenang. Anak yang dilahirkan dari perkawinaan yang tidak tercatat tidak dapat diakui oleh Negara sebagai anak yang sah dan anak tersebut tidak mempunyai hak baik yang bersifat yuridis maupun non yuridis yang mencakup hak keturunan anak, pemberian nafkah kepada anak, untuk dipelihara serta mendapat pendidikan, saling mewaris dari kedua orang tua, perwalian nikah bagi ayahnya untuk anak perempuan, serta hak lainya. 
Berdasarkan ketentuan UUP, anak luar kawin hanya memiliki hubungan keperdataan terhadap ibu yang melahirkan serta keluarganya (Masykuroh, 2016). Anak luar kawin dalam hal ini termasuk anak hasil perkawinan sirri karena perkawinan orang tua anak tersebut tidak tercatat dalam administrasi Negara sesuai ketentuan UU yang diberlakukan. Sehingga, berakibat anak yang lahir dari perkawinan tidak tercatat tidak berhak atas masalah keperdataan dengan ayahnya termasuk dalam permasalahan hak harisnya kelak, maka dari itu perlu adanya perlindungan hukum khususnya terhadap hak waris anak tersebut (Olivia, 2014).

Ada beberapa peneliti yang telah melakukan penelitian yang relevan dengan penelitian ini yaitu Erni Agustina, (2010) Perlu adanya perlindungan hukum bagi anak hasil perkawinan sirih, seba apabila tidak diciptakan oleh konsep hukum (social security, social walfare, dan human right) maka berarti anak-anak akan menjadi korban hukum yang mengakibatkan kerugian mereka yang seharusnya tidak mereka tanggung, selanjutnya Pancasilawati, (2014) melakukan penelitian tentang Perlindungan Hukum Bagi Hak-Hak Keperdataan Anak Luar Kawin. Penelitian lain Rusydi, (2019) meneliti tentang Tinjauan Yuridis terhadap Hak Waris Anak Hasil Perkawinan Siri. Walaupun sudah banyak penelitian tentang analisis pereturan tentang hak perlindungan hukum bagi anak hasil dari perkawinan yang tidak tercatat, namun sampai sekarang kasus ini semakin meningkat seperti pembagian harta warisan orang tua kepada anak yang tidak merasa adil. Oleh karena itu penelitian ini bertujuan untuk mendeskripsikan kedudukan anak yang dilahirkan dari perkawinan tidak dicatatkan sebagaimana ketentuan UUP dan menjelaskan perlindungan hukum bagi hak waris anak yang lahir dari perkawinan tidak tercatat

\section{METODE PENELITIAN}

Penelitian ini menggunakan penelitian hukum normatif atau penelitian hukum kepustakaan dengan pendekatan perundang-undangan dan pendekatan konseptual dikarenakan penelitian ini hanya ditujukan pada peraturan yang tertulis dan bahan hukum lainnya yang terkait dengan penelitian ini. Sumber bahan hukum yang digunakan adalah sumber bahan hukum primer yang terdiri dari UUD 1945, KUHPerdata, Undang-Undang Perkawinan dan Undang-Undang tentang Perlindungan Anak, sedangkan sumber bahan hukum sekunder terdiri dari makalah-makalah dan jurnal yang relevan dengan penelitian ini (Bambang, 2002).

\section{HASIL DAN PEMBAHASAN}

\section{Kedudukan Anak yang Dilahirkan dari Perkawinan Tidak Dicatatkan Sebagaimana Ketentuan UUP}

Anak diluar perkawinan yang sah adalah anak yang dilahirkan dari seorang wanita tanpa sebuah perkawinan sah dengan seorang pria yang membenihkan si anak dirahim si wanita, dan kedudukan anak yang dilahirkan tersebut tidak diakui dimata hukum layaknya anak sah pada umumnya. Sedangkan luar kawin merupakan hubungan antara pria dan wanita yang mempunyai keturunan namun hubungan si pria dan si wanita tanpa ikatan perkawinan yang sah menurut hukum positif.

Dalam UUP sahnya perkawinan terdapat dalam pasal 2 ayat (1) dan ayat (2) yaitu perkawinan adalah sah jika dilakukan berdasarkan masing-masing agama dan kepercayaannya serta perkawinan tersebut dicatat sesuai Undang-Undang yang berlaku. Sahnya perkawinan menurut UUP terdapat 2 pandangan yang berbeda, yaitu pertama menyatakan bahwa perkawinan itu sudah sah jika sudah dilakukan menurut pasal 2 ayat (1) yaitu dilakukan dengan agama dan kepercaannya tanpa perlu dicatat di Kantor Pencatatan Sipil, kedua mengatakan dalam pasal 2 ayat (1) dan (2) merupakan satu kesatuan yang tidak bisa dipisahkan maka, jika hanya satu unsur yang terpenuhi maka perkawinan itu tidak sah.

Dari uraian di atas, diketahui bahwa pandangan pertama sangat baik karena jika sudah melakukan perkawinan menurut agamanya masing-masing adalah sah. Karena melihat dari segi hukum adat di Bali, bahwa sepanjang perkawinan yang dilakukan berdasarkan upacara agama Hindu dan disaksikan oleh Brahmana atau Pendeta maka perkawinan tersebut sah dan melahirkan anak yang sah juga. Dalam UUP ini terdapat 2 macam status anak antara lain:

1. Anak sah yang terdapat dalam pasal 42 UUP adalah anak yang lahir dari seorang perempuan dan laki-laki yang berada dalam suatu ikatan yang sah menurut ketentuan agama dan di catat sesuai peraturan perundang-undangan 
2. Anak tidak sah (anak luar kawin), yaitu anak yang lahir dari perkawinan yang tidak sesuai dengan UUP N0. 1 Tahun 1974.

Dengan demikian bahwa status dan kedudukan anak yang lahir dari perkawinan tidak dicatatkan sebagaimana ketentuan Undang-Undang Nomor 1 Tahun 1974 adalah sebagai anak sah, tetapi tidak mempunyai kekuatan hukum untuk melakukan suatu perbuatan hukum yang menyangkut hak warisnya kelak. Meskipun perkawinan tersebut sah dimata agama namun anak yang dilahirkan tidak dapat diakui oleh Negara, maka dari itu perlu adanya perlindungan bagi anak yang lahir dari perkawinan tidak tercatat tersebut terutama yang menyangkut hak warisnya. Perlindungan hukum tersebut dapat berupa ukum publik dan privat yang bersifat yuridis serta perlindungan dalam bidang sosial, kesehatan dan bidang pendidikan yang bersifat non yuridis. Adapun istilah yang terdapat dalam hukum waris adalah sebagai berikut:

a. Pewaris, adalah orang yang meninggalkan harta kekayaan setelah ia meninggal dunia.

b. Ahli Waris, yaitu seorang yang menggantikan kedudukan warisan yang diberikan pewaris setelah meninggal dunia.

c. Harta Warisan, adalah seluruh harta kekayaan yang ditinggalkan oleh pewaris setelah meninggal dunia dipindah kepada ahli waris.

Sesuai ketentuan pasal 830 KUH Perdata bahwa pewarisan dapat terjadi jika pewaris telah meninggal dunia, dengan kata lain pewarisan tidak akan terjadi jika pewaris masih hidup. Di Indonesia ada 3 (tiga) sistem kewarisan, yaitu:

1. Sistem kewarisan hukum Islam bagi masyarakat yang beragama Islam

2. Sistem kewarisan Adat bagi masyarakat non Islam yang tunduk terhadap hukum adatnya masing-masing.

a. Sistem Patrilineal, yaitu sistem keturunan kebapakan.

b. Sistem Matrilineal, yaitu sistem keturunan keibuan.

c. Sistem parental, yaitu yang ditarik dari keturunan keibu-bapakan

3. Sistem kewarisan hukum Barat (KUH Perdata) bagi masyarakat keturunan Tionghoa yang tunduk terhadap ketentuan kewarisan KUH Perdata.

Dengan demikian, maka dapat dikatakan bahwa mengenai hukum waris pada KUH Perdata berlaku untuk masyarakat yang tunduk pada KUH Perdata, khususnya WNI keturunan Eropa dan karena belum ada UU yang mengaturnya secara khusus, maka KUH Perdata masih dapat diterapkan. Hukum Waris terdapat pada buku II KUH Perdata Pasal 830 sampai 1130 yang berkaitan dengan hukum kebendaan. Dalam KUH Perdata dimana hukum waris adalah kesemuanya kaidah yang mengatur nasib harta kekayaan apabila ia meninggal dunia, kekayaan tersebut berupa aktiva dan pasiva dan berupa hak dan kewajiban yang akan beralih dari pewaris setelah meninggal kepada ahli waris.

\section{Perlindungan Hukum Bagi Hak Waris Anak yang Lahir dari Perkawinan Tidak Tercatat}

Ketentuan yang terdapat dalam Pasal 832 KUH Perdata telah memperjelas bahwa kedudukan setiap ahli waris harus didasarkan pada suatu hubungan keluarga yang sah ataupun luar kawin. Dalam pasal 863-873 KUH Perdata, sehingga anak yang berhak mendapat warisan yaitu anak luar kawin yang dapat diakui atau anak yang disahkan saat perkawinan antara ayah dan ibunya dilangsungkan. Hal ini yang berhak menjadi ahli waris yaitu anak sah dan anak luar kawin yang mempunyai hubungan darah. Untuk dapat mewaris dari ayahnya harus melakukan pengakuan kedapa anak luar kawin sesuai ketentuan pasal 280 yang menyatakan bahwa dengan mengakui anak luar kawin maka timbulah hubungan perdata dengan ayah biologisnya. Pengakuan tersebut dapat dilakukan sesuai ketentuan KUH Perdata, yaitu pasal 281:

1. Berdasarkan kuasa otentik untuk dapat mengakui anak luar kawin bapak atau ibunya dan atau kuasanya harus bertemu pegawai pencatatan sipil untuk melaksanakan pengakuan kepada anak luar kawin sebagaimana ketentuan pasal 281 ayat (1) KUH Perdata.

2. Di dalam akta perkawinan memuat tentang pengakuan anak luar kawin yang boleh dilakukan saat perkawinan orangtuanya dilangsungkan sebagaimana diatur dalam Pasal 281 ayat (2) KUH Perdata. Akibat dari pengakuan ini adalah seorang anak luar kawin akan menjadi anak sah.

3. Berdasarkan pasal 281 ayat (1) KUH Perdata pengakuan terhadap anak luar kawin dilakukan dalam akta otentik seperti akta notaris. 
4. Akta yang dibuat dalam register kelahiran pencatatan sipil harus sesuai hari Penanggalannya sesuai ketentuan Pasal 281 ayat (2) KUH Perdata.

Dengan demikian pengakuan terhadap anak tersebut perlu dilakukan agar mendapat perlindungan hukum khususnya terhadap hak waris anak tersebut. Tanpa adanya bukti otentik perlindungan itu tidak dapat dilakukan karena tidak mempunyai kekuatan hukum. Sebagaimana telah dipahami bersama bahwa dalam hukum Islam suatu perkawinan siri merupakan perkawinan yang sah dimata hukum agama para pihaknya. Tetapi tidak memenuhi syarat sahnya perkawinan menurut hukum Negara. Sehingga perkawinan dan anak yang dilahirkan belum dapat diakui oleh Negara.

Perkawinan yang tidak dicatatkan pada prinsipnya perkawinan yang tidak sesuai dengan ketentuan hukum perkawinan yang berlaku (Tarihoran \& Yunanto, 2016). Meskipun keabsahan perkawinan menurut Agama Islam tidak terganggu, tetapi akibat dari tidak dicatatkannya perkawinan tersebut berimplikasi pada tidak adanya bukti otentik dalam hal ini akta perkawinan bahwa suami dan isteri telah melangsungkan perkawinan, sehingga tidak mempunyai kekuatan hukum, dan tidak dilindungi oleh hukum, serta dianggap tidak ada.

Dalam Hukum Islam bahwa apabila perkawinan sudah memenuhi syarat dan rukunnya maka perkawinan tersebut adalah sah namun, tidak mempunyai kekuatan hukum. Untuk dapat mendapatkan warisan terhadap ayahnya maka, harus mengajukan permohonan pengesahan status anak di Pengadilan untuk mendapat surat keterangan ahli waris (Milayani, 2017). Dengan demikian anak tersebut akan dilindungi apabila ada bukti otentik yang menyatakan anak tersebut sah. Jika ditinjau dari hukum waris adat Bali, anak yang bisa menjadi ahliwaris yaitu anak sah dan anak angkat. Ahli waris berhak untuk menuasai dan memiliki harta warisan dengan bagian yang ditentukan diantara ahli waris lainnya (Fauzi, 2016). Dalam hukum waris di Bali yang berhak mewaris adalah anak laki-laki dalam hubungan purusa. Syarat untuk menjadi ahli waris dalam hukum adat di Bali adalah Seorang yang mempunyai hubungan keluarga dan harus anak laki-laki. Dalam hukum waris adat ada 3 sistem kewarisan yaitu:

1. Sistem kewarisan kolektif, Sistem ini dimana harta peninggalannya sebagai satu kesatuan yang tidak dapat dibagi dari pewaris kepada ahli waris.

2. Sistem kewarisan mayorat adalah sistem pelimpahan untuk tanggung jawab kepada anak yang tertua sebagai pemimpin. Hal ini pada pewarisan terhadap karang desa yang dijumpai dalam masyarakat adat di Bali.

3. Sistem kewarisan individual, Sistem ini banyak kita jumpai pada masyarakat adat dengan garis keturunan secara parental.

Pada umumnya masyarakat adat Bali sistem kekeluargaan yang dianut adalah patrilineal serta sistem kewarisan yang dianut adalah sistem kewarisan individual, dimana ahli waris akan mewarisi harta warisan secara perorangan yang berupa tanah setelah pewaris meninggal. Namun, dalam kaitannya dengan kepemimpinan terhadap tanah ayahan desa dan karang desa barulah sistem mayorat sebab anak tertua yang menguasai harta dan seluruh kewajiban untuk mengasuh adiknya hingga dewasa. Kemudian juga pada masyarakat adat Bali berlaku kewarisan kolektif yaitu ahli waris akan mewarisi harta tersebut dengan bersama serta tidak dapat dibagi. Dengan demikian masyarakat di Bali menganut sistem kekeluargaan patrilineal dengan ketiga sistem kewarisan tersebut. Untuk dapat mewaris menurut hukum waris adat di Bali haruslah anak laki-laki dan adanya bukti otentik sebagai bukti tertulis bahwa anak itu memang berhak menjadi ahli waris dan mendapat warisan sesuai bagaiannya.

Pada umumnya baik ketentuan Hukum Waris KUH Perdata, Hukum Waris Islam, dan Hukum waris adat khususnya di Bali, anak dari perkawinan tidak tercatat akan mendapat perlindungan terhadap hak warisnya apabila anak tersebut diakui dan disahkan dan adanya akta otentik sebagai alat bukti tertulis yang sah. Jika tidak ada bukti otentik maka peralihan harta warisan dari pewaris setelah meninggal kepada ahli waris tidak bisa dilakukan.

\section{SIMPULAN DAN SARAN}

\section{Simpulan}

Berdasarkan hasil analisis data, dapat disimpulkan bahwa kedudukan anak yang lahir dari perkawinan tidak dicatatkan adalah sah jika perkawinan orang tuanya itu dilakukan menurut agama dan kepercayaannya yang terdapat dalam pasal 2 ayat (1), dengan demikian anak yang dilahirkan sah pula akan tetapi karena perkawinan tersebut tidak dicatatkan, tidak memiliki kekuatan hukum untuk 
melakukan suatu perbuatan hukum, yang kedua Bentuk perlindungan terhadap hak waris anak yang lahir dari perkawinan tidak tercatat adalah anak tersebut mendapat warisan jika diakui oleh ayah biologisnya berupa adanya akta otentik (akta kelahiran) sebagai alat bukti bahwa anak tersebut adalah sah dan berhak mendapat warisan sesuai dengan penundukan hukum waris yang berlaku di Indonesia, bagi masyarakat agama Islam tunduk terhadap hukum waris Islam, bagi masyarakat non Islam tunduk terhadap hukum waris adat masing-masing, dan bagi masyarakat keturunan Eropa berlaku hukum waris Perdata Barat (Kitab Undang-Undang Hukum Perdata).

\section{Saran}

Berdasarkan pembahasan dan realitas, adapun saran yang dapat disampaikan, untuk masyarakat disarankan agar dalam melakukan suatu perbuatan perkawinan sebaiknya dicatatkan sesuai aturan hukum yang berlaku sehingga tidak menimbulkan masalah dikemudian hari, karena di Negara kita adalah Negara hukum agar perkawinan dan anak yang dilahirkan mendapat perlindungan, selanjutnya untuk pemerintah sebaiknya dalam ketentuan pasal 2 ayat (1) dan (2) harus ada ketegasan sehingga tidak terdapat perbedaan pandangan dalam sahnya suatu perkawinan dan kepada pemerintah Pencatatan Sipil perlu mensosialisasikan kepada masyarakat bahwa pentingnya suatu pencatatan perkawinan.

\section{DAFTAR PUSTAKA}

Bambang, W. (2002). Penelitian Hukum dalam Praktek. Sinar Grafika.

Erni Agustina. (2010). Perlindungan Hak Mewaris Seorang Anak Hasil Perkawinan Ijab Qabul Tidak Tercatat pada Hukum Negara. Lex Jurnalica, 8(1), 73-85.

Fauzi, M. Y. (2016). Legislasi Hukum Islam di Indonesia. Jurnal Pengembangan Masyarakat Islam, 9(2), 5376.

Masykuroh, Y. W. R. (2016). Implikasi Hubungan Perdata Anak Luar Perkawinan dengan Laki-Laki Sebagai Ayahnya. Journal of Materials Processing Technology, 9(2), 25-52. Masykuroh, Y. W. R. (2016). Implikasi Hubungan Perdata Anak Luar Perkawinan dengan Laki-Laki Sebagai Ayahnya. Journal of Materials Processing Technology, 9(2), 25-52.

Milayani, O. (2017). Kedudukan Hukum Ahli Waris yang Mewaris dengan Cara Mengganti Atau Bij Plaatsvervulling' Menurut Burgerlijk Wetboek. Al' Adi, 9(3), 405-434.

Olivia, F. (2014). Akibat Hukum Terhadap Anak Hasil Perkawinan Siri Pasca Putusan Mahkamah Konstitusi. Lex Jurnalica Volume, 11(2), 130-142.

Pancasilawati, A. (2014). Perlindungan Hukum Bagi Hak-Hak Keperdataan Anak Luar Kawin. Fenomena, 6(2), $171-216$.

Rusydi, I. (2019). Tinjauan Yuridis terhadap Hak Waris Anak Hasil Perkawinan Siri. Jurnal Ilmiah Galuh Justisi, 7(1), 49-58.

Tarihoran, S. P. M., \& Yunanto, H. W. (2016). Praktik Pelaksanaan Perkawinan yang Tidak Dicatatkan (Studi di Lembaga Pencatatan Perkawinan di Kota Semarang). Diponegoro Law Journal, 5(3), 1-12.

Usman, R. (2017). Makna Pencatatan Perkawinan dalam Peraturan Perundang-Undangan Perkawinan di Indonesia. Jurnal Legislasi Indonesia, 14(3), 255-274. 